\title{
Peroxisome Proliferator-Activated Receptor- $\gamma$ Coactivator-1 $\alpha$ Polymorphism Is Not Associated with Essential Hypertension and Type 2 Diabetes Mellitus in Chinese Population
}

\author{
Shufeng $\mathrm{CHEN}^{*, * * *}$, Weili YAN ${ }^{*}{ }^{* * *}$, Jianfeng $\mathrm{HUANG}^{*}$, Wenjie YANG ${ }^{*}$, \\ and Dongfeng $\mathrm{GU}^{*}, * *$
}

\begin{abstract}
To investigate whether variations in the peroxisome proliferator-activated receptor $\gamma$ coactivator-1a $(P G C$ - $t a)$ are associated with essential hypertension and type 2 diabetes in a Chinese population. A case-control study design was applied in a Chinese population. Two single nucleotide polymorphisms (SNPs), + 1302G > $A$ and G482S, in the PGC-ta gene were genotyped and compared between 494 unrelated Chinese subjects with essential hypertension and type 2 diabetes and 555 normal control subjects with the polymerase chain reaction-restriction fragment length polymorphism (PCR-RFLP) method. These two polymorphisms were in highly significant linkage disequilibrium with each other $(p<0.0001)$. The frequency of the $482 S$ allele was 42.9\% in the Chinese population, which was similar to the frequency in the Japanese population (43.7\%), but much higher than those of Caucasian populations $(30.8 \%$ to $38.1 \%)$. There were no associations of the G482S and +1302G $>$ A polymorphisms and haplotype combinations with essential hypertension and type 2 diabetes. In addition, no associations were found between these two polymorphisms and blood pressure. In conclusion, these results indicated that these two variations in the PGC-ta gene might not contribute to the risk of hypertension and type 2 diabetes in the Chinese population studied here.
\end{abstract}

(Hypertens Res 2004; 27: 813-820)

Key Words: hypertension, type 2 diabetes, peroxisome proliferator-activated receptor- $y$ coactivator-1a, association study

\section{Introduction}

Hypertension and type 2 diabetes mellitus (T2DM) are components of metabolic syndrome (1). In most patients with hypertension, insulin resistance and hyperinsulinemia are present and may contribute to the pathogenesis of hypertension
$(2,3)$. The diverse prevalence rates of hypertension and T2DM within and among populations suggest that these two diseases are caused by interaction between environmental and genetic factors (4). However, many of the molecular details have not been fully elucidated (5). Peroxisome proliferator-activated receptor (PPAR)- $\gamma$ coactivator $1 \alpha(P G C-1 \alpha$, also named PPARGC1A, Gene ID, No. 10891) has been iden-

From the ${ }^{*}$ Division of Population Genetics and Prevention, Fu Wai Hospital, Chinese Academy of Medical Sciences and Peking Union Medical College, Beijing PR China, and ${ }^{* *}$ National Human Genome Center at Beijing, Beijing, PR China.

${ }^{* * *}$ These two authors are joint first authors.

This study was funded by a contractual agreement among the National Human Genome Center at Beijing, Cardiovascular Institute and Fu Wai Hospital of the Chinese Academy of Medical Sciences and Peking Union Medical College, and Roche Genetics, F. Hoffmann-La Roche Ltd., Switzerland. However, the study was conducted, analyzed, and interpreted by the investigators independently of the sponsors.

Address for Reprints: Dongfeng Gu, M.D., M.S., Division of Population Genetics and Prevention, Cardiovascular Institute and Fu Wai Hospital, Chinese Academy of Medical Sciences and Peking Union Medical College, 167 Beilishi Road, Beijing 100037, China. E-mail: gudf@yahoo.com Received April 6, 2004; Accepted in revised form July 16, 2004. 
tified as a transcriptional coactivator of PPAR $\alpha$ and $\gamma$, which are involved in adipogenesis and fatty acid $\beta$-oxidation, and other nuclear receptors which participate in blood pressure control $(6,7) . P G C-1 \alpha$ plays an important role in several aspects of oxidative metabolism: glucose uptake, the signaling pathway of insulin, and control of the level of endogenous glucose transporter (GLUT4) expression in muscle cells (8). Recent studies showed that $P G C-1 \alpha$ was a critical modulator of hepatic gluconeogenesis and a central target of the insulin-cAMP axis in the liver (9). The $P G C$ - $1 \alpha$ gene was mapped to chromosome $4 \mathrm{p} 15.1$, a region that has been shown to be associated with systolic blood pressure (SBP), fasting insulin level, abdominal subcutaneous fat, and plasma free-fatty acids level (10-13). Several studies have determined that single nucleotide polymorphisms (SNPs) in the $P G C-1 \alpha$ gene had effects on the pathogenesis of essential hypertension or T2DM. And yet the replicability of the results was poor (14-17). Due to the intimate relationship between hypertension and diabetes, in the present study we aimed to verify the association of the $+1302 \mathrm{G}>\mathrm{A}$ (a silent transition at amino acid position 394 in exon 8) and G482S (a G-to-A transition that predicted a glycine $(\mathrm{G})$ to serine $(\mathrm{S})$ substitution at amino acid position 482 in exon 8) polymorphisms in the $P G C-1 \alpha$ gene with hypertension and T2DM in a Chinese population.

\section{Methods}

\section{Subjects}

In the present study, 494 subjects with essential hypertension complicated with T2DM and 555 control subjects were enrolled. All subjects (aged 25-75 years) were randomly recruited from the northern area in China. Hypertension was defined as an average SBP $\geq 160 \mathrm{mmHg}$, an average diastolic blood pressure (DBP) $\geq 90 \mathrm{mmHg}$, and/or current use of antihypertensive medications. Diabetes was diagnosed as a fasting serum glucose concentration $\geq 126 \mathrm{mg} / \mathrm{dl} \quad(7.0 \mathrm{mmol} / \mathrm{l})$ and/or use of hypoglycemic medications. All control subjects had normal blood pressure (blood pressure $<135 / 85$ $\mathrm{mmHg}$ ) and normoglycemia (fasting glucose $<100 \mathrm{mg} / \mathrm{dl}$ $(5.6 \mathrm{mmol} / \mathrm{l}))$, and no history of diabetes or hypertension. Subjects were excluded if they had one of the following: secondary hypertension, type 1 diabetes, pregnancy, dysfunction of the liver or kidney, disease of the thyroid or hypothalamus, and history of coronary heart disease, stroke or cancer. The protocol was approved by the local bioethical committee and performed after informed written consent was obtained from all participants.

The present age of all participants and the age at onset of hypertension and diabetes were obtained from direct interviews by trained interviewers. After an initial screen including blood pressure according to the enrollment criteria, three blood pressure measurements were taken from each participant using a standard mercury sphygmomanometer by trained and certified observers according to a common protocol adapted from procedures recommended by the American Heart Association (18). Anthropometric measurements, such as height, weight, and waist and hip circumferences, were also obtained from all participants. Body mass index (BMI) was calculated by the measurements of weight and height. A BMI of $28 \mathrm{~kg} / \mathrm{m}^{2}$ may identify the risk factors related to chronic diseases, such as diabetes mellitus and lipoprotein disorders, with a specificity of around $90 \%$ (19). In another study, the odds ratio (OR) for clustering of hypertension, myocardial infarction and stroke was remarkably elevated in patients with a BMI $\geq 28 \mathrm{~kg} / \mathrm{m}^{2}(20)$. And age-adjusted allcause mortality has been shown to increase in patients with a BMI higher than $28 \mathrm{~kg} / \mathrm{m}^{2}(21)$. Based on these findings from several recent large-scale epidemiological studies in China, a BMI of $28 \mathrm{~kg} / \mathrm{m}^{2}$ was recommended as the cut-off point for obesity in the Chinese population by the Working Group on Obesity in China. In this study, we defined individuals as obese when their BMI was $\geq 28 \mathrm{~kg} / \mathrm{m}^{2}$.

The mean age of patients (246 men, 248 women) was $57.20 \pm 9.38$ years, and the mean ages of diagnosis of hypertension and diabetes were 48.99 \pm 12.02 and $53.47 \pm 9.50$ years, respectively. Durations of hypertension and diabetes were $8.21 \pm 10.06$ and $3.73 \pm 5.00$ years, respectively. In the group of normal control subjects ( 288 men, 267 women), the average age was $56.49 \pm 8.73$ years. All subjects enrolled in this study were unrelated, were residents of northern China, and were of Han ethnicity.

\section{Biological Measurements}

Blood samples were drawn after an overnight fast, and the serum was segregated for biochemical analysis within $2 \mathrm{~h}$. All samples were stored at $-70^{\circ} \mathrm{C}$. Serum total cholesterol (TC), triglycerides (TG), high-density lipoprotein cholesterol (HDLc) and glucose were measured on a Hitachi ${ }^{\circledR} 7060$ automatic analyzer (Hitachi, Tokyo, Japan) by enzymatic methods. The Lipid Research Laboratory of the Disease Control and Prevention Center (Atlanta, USA) provided serum for quality control.

\section{Detecting Genotypes of SNPs}

Genomic DNA for analyses was isolated from blood leukocytes by the standard salt precipitation method. The polymerase chain reaction-restriction fragment length polymorphism (PCR-RFLP) method was used to detect the genotypes of these two SNPs. The sequences of the primers used to analyze the $+1302 \mathrm{G}>$ A polymorphisms were $5^{\prime}$-GCCAG TCAATTAATTCCAAACC-3', containing one single-base mismatch (underlined) (14), and 5'-CTTGCCTCCAAAGTC TCTC-3'. The sequences of the primers used to assess the G482S polymorphism were 5'-TTGTTCTTCCACAGATT CAGAC-3' and 5'-GAAAAGGACCTTGAACGAGAG-3'. Optimum PCR amplification conditions were achieved with 
$1 \times$ PCR buffer, $2 \mathrm{mmol} / 1 \mathrm{MgCl}_{2}, 0.15 \mu \mathrm{mol} / \mathrm{l}$ of each primer, $0.2 \mathrm{mmol} / \mathrm{l} \mathrm{dNTP}$ and $1 \mathrm{IU}$ AmpliTaq polymerase. The quantity of genomic DNA was $50 \mathrm{ng}$ for the two polymorphisms. The cycling program for PCR of these two polymorphisms consisted of a denaturation step at $95^{\circ} \mathrm{C}$ for $5 \mathrm{~min}, 35$ cycles of denaturation at $94^{\circ} \mathrm{C}$ for $50 \mathrm{~s}$, annealing at $56^{\circ} \mathrm{C}$ (for the $+1302 \mathrm{G}>\mathrm{A}$ ) or $58^{\circ} \mathrm{C}$ (for the G482S) for $40 \mathrm{~s}$, extension at $72^{\circ} \mathrm{C}$ for $50 \mathrm{~s}$, and then a final extension step at $72^{\circ} \mathrm{C}$ for 8 min. PCR products were digested overnight at $37^{\circ} \mathrm{C}$ with MspI (TaKaRa Biotechnology Co., Ltd., Tokyo, Japam) for these two polymorphisms followed by detection on $3 \%$ ethidium bromide-stained agarose gels.

\section{Statistical Analysis}

Transformations of continuous variables were made if the equal variance and normal distribution were rejected. Basic continuous characteristics between case and control subjects were analyzed by Student's $t$-test. The $\chi^{2}$ and Fisher's exact test were used to compare the categorical variables of gender, alleles, genotypes, and haplotypes between groups, and to verify agreement with Hardy-Weinberg expectations. The Estimation Haplotype-frequencies software (EH) (http:// linkage.rockefeller.edu/software/eh) and PHASE program (http://www.stat.washington.edu/stephens/) were used to estimate frequency distributions of haplotypes and haplotype combinations. The standardized linkage disequilibrium statistic $\left(r^{2}\right)$ was estimated using ldmax software (http://www. sph.umich.edu/csg/abecasis/GOLD/). The statistical power of this study was estimated using the Power Calculator program (http://calculators.stat.ucla.edu/powercalc/).

The general linear model was used to test quantitative variables for differences among genotypic groups adjusting for covariate variables of age, gender, and BMI where appro- priate. To estimate OR with $95 \%$ confidence intervals (CI) for each genotype, 2 "dummy" variables with the respective wild-type as the reference were used in multivariate logistic regression analysis adjusted for age, gender, BMI, smoking and drinking status (22).

The OR and $95 \%$ CI of each haplotype combination relative to the other haplotype combinations as a group were determined by the method of Horikawa et al. (23). In agreement with a previous Japanese study, there was a strong linkage disequilibrium between the two polymorphisms, with the

Table 1. Comparison of Basic Characteristics between Cases and Controls

\begin{tabular}{lccr}
\hline & $\begin{array}{c}\text { Cases } \\
(n=494)\end{array}$ & $\begin{array}{c}\text { Controls } \\
(n=555)\end{array}$ & $p$ \\
\hline Age (years) & $57.20 \pm 9.38$ & $56.49 \pm 8.73$ & 0.2019 \\
Gender $(\mathrm{M} / \mathrm{F})$ & $246 / 248(49.8 \%)$ & $288 / 267(51.89 \%)$ & 0.4980 \\
SBP $(\mathrm{mmHg})$ & $148.31 \pm 18.55$ & $118.45 \pm 9.84$ & 0.0001 \\
DBP $(\mathrm{mmHg})$ & $88.02 \pm 11.59$ & $73.98 \pm 6.71$ & 0.0001 \\
Waist circle $(\mathrm{cm})$ & $93.27 \pm 10.39$ & $81.84 \pm 9.15$ & 0.0001 \\
BMI $\left(\mathrm{kg} / \mathrm{m}^{2}\right)$ & $27.11 \pm 3.64$ & $23.73 \pm 2.99$ & 0.0001 \\
Glucose $(\mathrm{mmol} / \mathrm{l})$ & $9.20 \pm 2.95$ & $4.96 \pm 0.38$ & 0.0001 \\
TC $(\mathrm{mmol} / \mathrm{l})$ & $5.39 \pm 1.07$ & $5.10 \pm 0.97$ & 0.0001 \\
TG $(\mathrm{mmol} / \mathrm{l})$ & $1.93 \pm 1.05$ & $1.26 \pm 0.62$ & $<0.0001$ \\
HDLc $(\mathrm{mmol} / \mathrm{l})$ & $1.15 \pm 0.27$ & $1.34 \pm 0.35$ & 0.0001 \\
LDLc $(\mathrm{mmol} / \mathrm{l})$ & $3.33 \pm 0.88$ & $3.19 \pm 0.85$ & 0.0075 \\
Smokers & $172(34.82 \%)$ & $177(31.89 \%)$ & 0.3150 \\
Drinkers & $112(22.67 \%)$ & $102(18.38 \%)$ & 0.0850 \\
\hline
\end{tabular}

SBP, systolic blood pressure; DBP, diastolic blood pressure; BMI, body mass index; TC, total cholesterol; TG, triglyceride; HDLc, high-density lipoprotein cholesterol; LDLc, low-density lipoprotein cholesterol.

Table 2. Genotype and Haplotype Frequencies of PGC-1 $\alpha$ Polymorphisms in the Study Subjects

\begin{tabular}{|c|c|c|c|c|}
\hline SNP & Genotypes/alleles & $\begin{array}{c}\text { Case } \\
(n=494)\end{array}$ & $\begin{array}{l}\text { Control } \\
(n=555)\end{array}$ & $p$ \\
\hline \multirow[t]{5}{*}{$+1302 \mathrm{G}>\mathrm{A}$} & GG & $305(61.74 \%)$ & $340(61.26 \%)$ & \\
\hline & GA & $164(33.20 \%)$ & $186(33.51 \%)$ & \\
\hline & $\mathrm{AA}$ & $25(5.06 \%)$ & $29(5.23 \%)$ & 0.984 \\
\hline & G-allele & $774(78.34 \%)$ & $866(78.02 \%)$ & \\
\hline & A-allele & $214(21.66 \%)$ & $244(21.98 \%)$ & 0.859 \\
\hline \multirow[t]{5}{*}{ G482S } & GG & $155(31.38 \%)$ & $185(33.33 \%)$ & \\
\hline & GS & $255(51.62 \%)$ & $264(47.57 \%)$ & \\
\hline & SS & $84(17.00 \%)$ & $106(19.10 \%)$ & 0.405 \\
\hline & G-allele & $565(57.19 \%)$ & $634(57.12 \%)$ & \\
\hline & S-allele & $423(42.81 \%)$ & $476(42.88 \%)$ & 0.975 \\
\hline \multirow[t]{4}{*}{ Haplotype } & $+1302 \mathrm{G}-482 \mathrm{~S}$ & $420(42.51 \%)$ & $473(42.61 \%)$ & \\
\hline & $+1302 \mathrm{G}-482 \mathrm{G}$ & $354(35.83 \%)$ & $393(35.41 \%)$ & \\
\hline & $+1302 \mathrm{~A}-482 \mathrm{G}$ & $211(21.36 \%)$ & $241(21.71 \%)$ & \\
\hline & $+1302 \mathrm{~A}-482 \mathrm{~S}$ & $3(0.30 \%)$ & $3(0.27 \%)$ & 0.994 \\
\hline
\end{tabular}

$P G C-1 \alpha$, peroxisome proliferator-activated receptor- $\gamma$ coactivator- $1 \alpha$. 
six most common haplotype combinations accounting for $99.6 \%$ of all haplotype combinations. The frequencies of the rare haplotype combinations (+1302AA-482SS, + 1302GA$482 \mathrm{SS},+1302 \mathrm{AA}-482 \mathrm{GS}$ ) accounting for less than $0.5 \%$ were ignored (24). All analyses were done using Statistical Analysis System software (SAS Institute, Cary, USA). A pvalue of less than 0.05 (two-tailed) was considered statistically significant.

\section{Results}

In the present study, in comparison to controls, cases with hypertension and diabetes had higher BMI and higher levels of TC, low-density lipoprotein cholesterol (LDLc) and TG, and lower levels of HDLc, in addition to higher blood pressure and concentration of serum glucose. The proportions of smokers $(34.82 \%$ vs. $31.89 \%, p=0.315)$ and drinkers (22.67\% vs. $18.38 \%, p=0.085)$ in patients were similar to those in normal subjects (Table 1 ).

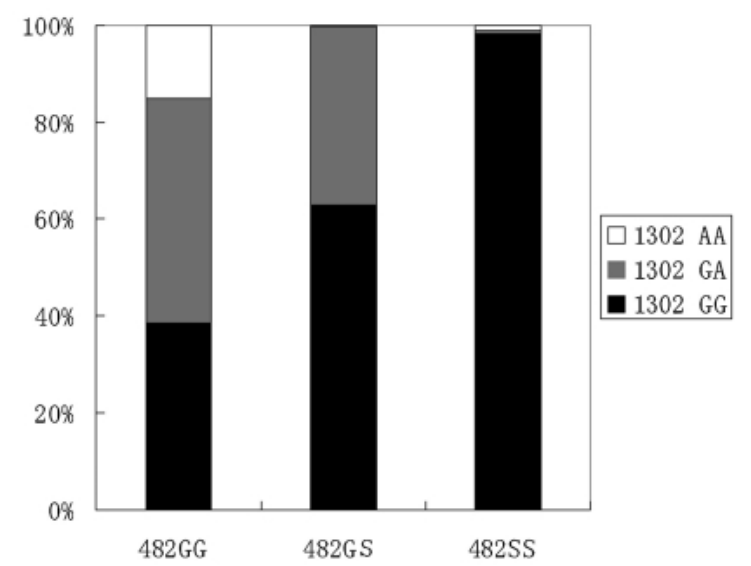

Fig. 1. PGC- $1 \alpha+1302 G>A$ genotypes distribution as a function of $\mathrm{PGC}-1 \alpha$ G482S genotypes $(\mathrm{p}=0.001)$.
Genotypic distributions at these two polymorphic sites were both in agreement with Hardy-Weinberg equilibrium in all subjects. Distributions of genotypic and allelic frequencies of these two polymorphisms in the case group were not statistically different from those in the control group (Table 2 ). In all subjects, these two polymorphisms were in highly significant linkage disequilibrium with each other $\left(r^{2}=0.19\right.$, $p<0.0001)$. Figure 1 shows that the frequency of the $+1302 \mathrm{~A}$ allele appeared to increase significantly from non$482 \mathrm{G}$ allele carriers to homozygous $482 \mathrm{GG}$ carriers; moreover, the homozygous + 1302AA genotype almost coexisted in individuals with the homozygous 482GG genotype. These results suggested that the minor $+1302 \mathrm{~A}$ allele segregated with the common $482 \mathrm{G}$ allele. The frequencies of each haplotype estimated by either the Phase $(p=0.994)$ or EH program (data not shown) did not differ between the case and control groups. The frequencies of haplotype combinations $(p=0.892)$ estimated by the Phase program also did not differ between the two groups. Gender-specific analysis also showed no significant differences in the genotype, allele or haplotype combination frequencies (data not shown). As shown in Table 3 , the ORs of haplotype combinations ranged from 0.850 to 1.138 , with all $p$ values being greater than 0.35 ; none of the haplotype combinations were classified as increasing the risk of hypertension or diabetes.

Among obese subjects with BMI $\geq 28 \mathrm{~kg} / \mathrm{m}^{2}$, there were 189 hypertensive patients with diabetes (HD-OB subgroup) (male/female, 95/94; mean age, 54.97 \pm 9.23 years; mean BMI, $30.71 \pm 2.49 \mathrm{~kg} / \mathrm{m}^{2}$ ) and 44 control subjects (OB subgroup) (male/female, 17/27; mean age, 56.77 \pm 8.40 years; mean BMI, $29.96 \pm 1.96 \mathrm{~kg} / \mathrm{m}^{2}$ ); while there were 304 hypertensive patients with diabetes (HD-NOB subgroup) (male/female, 151/153; mean age, 58.58 \pm 9.24 years; mean BMI, $24.86 \pm 2.13 \mathrm{~kg} / \mathrm{m}^{2}$ ) and 508 control subjects (NOB subgroup) (male/female, 268/240; mean age, 56.46 \pm 8.78 years; mean BMI, $23.19 \pm 2.40 \mathrm{~kg} / \mathrm{m}^{2}$ ) among non-obese subjects. Stratification analysis based on obesity revealed no signifi-

Table 3. Risk of Hypertension and Diabetes by Haplotype Combinations

\begin{tabular}{lcccc}
\hline Haplotype combination & $\begin{array}{c}\text { Case } \\
(n=494)\end{array}$ & $\begin{array}{c}\text { Control } \\
(n=555)\end{array}$ & OR (95\% CI) & $p$ \\
\hline$+1302 \mathrm{GG}-482 \mathrm{GS}$ & $159(32.19 \%)$ & $168(30.27 \%)$ & $1.093(0.842-1.420)$ & 0.504 \\
+ 1302GG-482SS & $83(16.80 \%)$ & $104(18.74 \%)$ & $0.876(0.637-1.204)$ & 0.413 \\
+ 1302GA-482GS & $95(19.23 \%)$ & $96(17.30 \%)$ & $1.138(0.832-1.558)$ & 0.418 \\
+ 1302GA-482GG & $69(13.97 \%)$ & $89(16.04 \%)$ & $0.850(0.605-1.195)$ & 0.350 \\
$+1302 \mathrm{GG}-482 \mathrm{GG}$ & $63(12.75 \%)$ & $68(12.25 \%)$ & $1.047(0.726-1.510)$ & 0.807 \\
$+1302 \mathrm{AA}-482 \mathrm{GG}$ & $23(4.66 \%)$ & $28(5.05 \%)$ & $0.919(0.522-1.618)$ & 0.770 \\
Others & $2(0.4 \%)$ & $2(0.36 \%)$ & NA & NA \\
\hline
\end{tabular}

NA, not analyzed. The odds ratio (OR) and 95\% confidence interval (CI) of each haplotype combination relative to all other haplotype combinations as a group are shown, as in Horikawa et al. (23). In agreement with a previous Japanese study, there was strong linkage disequilibrium between the two polymorphisms, with the six most common haplotype combinations accounting for $99.6 \%$ of all haplotype combinations. The frequencies of the rare haplotype combinations (+1302AA-482SS, +1302GA-482SS, +1302AA-482GS) accounting for less than $0.5 \%$ were ignored (24). 
Table 4. Genotype and Allele Frequencies of PGC-1 $\alpha$ Polymorphisms in the Study Subjects Stratified Based on Obesity $\left(B M I \geq 28 \mathrm{~kg} / \mathrm{m}^{2}\right)$

\begin{tabular}{|c|c|c|c|c|c|c|}
\hline & \multicolumn{3}{|c|}{ Obese } & \multicolumn{3}{|c|}{ Non-obese } \\
\hline & $\begin{array}{l}\text { HD-OB } \\
(n=189)\end{array}$ & $\begin{array}{c}\text { OB } \\
(n=44)\end{array}$ & $p$ & $\begin{array}{l}\text { HD-NOB } \\
(n=304)\end{array}$ & $\begin{array}{c}\text { NOB } \\
(n=508)\end{array}$ & $p^{*}$ \\
\hline$+1302 \mathrm{GG}$ & $112(59.26 \%)$ & $25(56.82 \%)$ & & $192(63.16 \%)$ & $313(61.61 \%)$ & \\
\hline$+1302 \mathrm{GA}$ & $68(35.98 \%)$ & $18(40.91 \%)$ & & $96(31.58 \%)$ & $167(32.87 \%)$ & \\
\hline$+1302 \mathrm{AA}$ & $9(4.76 \%)$ & $1(2.27 \%)$ & 0.6749 & $16(5.26 \%)$ & $28(5.51 \%)$ & 0.908 \\
\hline$+1302 \mathrm{G}$ allele & $292(77.25 \%)$ & $68(77.27 \%)$ & & $480(78.95 \%)$ & $793(78.05 \%)$ & \\
\hline$+1302 \mathrm{~A}$ allele & $86(22.75 \%)$ & $20(22.73 \%)$ & 0.996 & $128(21.05 \%)$ & $223(21.95 \%)$ & 0.671 \\
\hline $482 \mathrm{GG}$ & $59(31.22 \%)$ & $21(47.73 \%)$ & & $96(31.58 \%)$ & $164(32.28 \%)$ & \\
\hline $482 \mathrm{GS}$ & $96(50.79 \%)$ & $15(34.09 \%)$ & & $158(51.97 \%)$ & $247(48.62 \%)$ & \\
\hline $482 \mathrm{SS}$ & $34(17.99 \%)$ & $8(18.18 \%)$ & 0.0852 & $50(16.45 \%)$ & $97(19.09 \%)$ & 0.5505 \\
\hline $482 \mathrm{G}$ allele & $214(56.61 \%)$ & $57(64.77 \%)$ & & $350(57.57 \%)$ & $575(56.59 \%)$ & \\
\hline $482 \mathrm{~S}$ allele & $164(43.99 \%)$ & $31(35.23 \%)$ & 0.1623 & $258(42.43 \%)$ & $441(43.41 \%)$ & 0.702 \\
\hline
\end{tabular}

HD-OB: subjects with type 2 diabetes, essential hypertension and body mass index (BMI) $\geq 28 \mathrm{~kg} / \mathrm{m}^{2}$; OB: simple obese subjects $\left(\mathrm{BMI} \geq 28 \mathrm{~kg} / \mathrm{m}^{2}\right)$ without diabetes or hypertension; HD-NOB: type 2 diabetic patients with essential hypertension and $\mathrm{BMI}<28 \mathrm{~kg} / \mathrm{m}^{2}$; NOB: normal control subjects with BMI $<28 \mathrm{~kg} / \mathrm{m}^{2}$. ${ }^{*}$ Genotypes are missing for 1 patient and 3 control subjects. $P G C-1 \alpha$, peroxisome proliferator-activated receptor- $\gamma$ coactivator- $1 \alpha$.

cant differences in genotype, allele, or haplotype combination frequencies (Table 4).

Multivariate logistic regression analysis showed that, in the additive model, genotypes at two polymorphic sites were not associated with hypertension or diabetes $(482 \mathrm{GS}, \mathrm{OR}=$ $1.228,95 \% \mathrm{CI}=0.881-1.712 ; 482 \mathrm{SS}, \quad \mathrm{OR}=0.932,95 \%$ $\mathrm{CI}=0.594-1.462 ; 1302 \mathrm{GA}, \mathrm{OR}=0.864,95 \% \mathrm{CI}=0.626-$ $1.192 ; 1302 \mathrm{AA}, \mathrm{OR}=0.970,95 \% \mathrm{CI}=0.492-1.912$ ). The findings of logistic regression analysis indicated that age and BMI had important effects on the risk of hypertension or diabetes, when adjusted for confounding effects from gender, smoking and drinking habits (Table 5).

\section{Discussion}

PPAR $\gamma$ is a transcription factor and molecular target of the thiazolidinedione class of agents, which have been shown to lower fasting blood glucose (25). A meta-analysis including 3,000 individuals from earlier studies reported that the more common proline allele in the PPAR $\gamma$ gene was associated with a significantly increased risk of diabetes (1.25-fold), which translated into a large population attributable risk of about $25 \%$ (26). PPAR $\gamma$ and its ligands suppress angiotensin II (AII) type 1 receptor (AT1R) gene expression $(27,28)$. AII activates membrane AT1R and then triggers a variety of signal transduction pathways, including the mitogen-activated protein (MAP) kinase pathway. AII exerts many biological effects and contributes to the progression of hypertension and atherosclerosis (29-31). PPAR $\gamma$ phosphorylation by the MAP kinase pathway may thus attenuate PPAR $\gamma$-mediated AT1R gene transcription suppression through the inhibition of PPAR $\gamma$ activity (32). Therefore, it is reasonable to assume that PPAR $\gamma$ plays a role in hypertension by regulating AT1R
Table 5. Multivariate Logistic Regression Results of G482S and G1302A Polymorphisms in the PGC-1 $\alpha$ Gene in all Subjects

\begin{tabular}{lcccc}
\hline \multirow{2}{*}{ Variable } & \multirow{2}{*}{ OR } & \multicolumn{2}{c}{$95 \%$ CI } & \multirow{2}{*}{$p$} \\
\cline { 3 - 4 } & & Lower & Upper & \\
\hline Age & 1.023 & 1.007 & 1.039 & 0.0043 \\
Gender, M/F & 0.879 & 0.631 & 1.225 & 0.4466 \\
BMI & 1.382 & 1.317 & 1.450 & 0.0001 \\
Smoking, Y/N & 1.099 & 0.757 & 1.596 & 0.6182 \\
Drinking, Y/N & 1.324 & 0.883 & 1.987 & 0.1748 \\
482GS & 1.228 & 0.881 & 1.712 & 0.2253 \\
482SS $^{*}$ & 0.932 & 0.594 & 1.462 & 0.7584 \\
1302GA $^{\#}$ & 0.864 & 0.626 & 1.192 & 0.3726 \\
1302AA $^{\#}$ & 0.970 & 0.492 & 1.912 & 0.9294 \\
\hline
\end{tabular}

Independent variable: hypertension and diabetes status. OR, odds ratio; CI, confidence interval; $\mathrm{Y}$, yes; $\mathrm{N}$, no. ${ }^{*}$ The relative risks associated with the 482GS and 482SS genotypes were estimated in comparison with the $482 \mathrm{GG}$ genotype. ${ }^{\#}$ The relative risks associated with the 1302GA and 1302AA genotypes were estimated in comparison with the $1302 \mathrm{GG}$ genotype. $P G C-1 \alpha$, peroxisome proliferator-activated receptor- $\gamma$ coactivator- $1 \alpha$.

gene expression. As a coactivator of PPAR $\gamma$ and other nuclear genes, $P G C$ - $1 \alpha$ regulates PPAR $\gamma$ and nuclear respiratory factor (NRF)-dependent transcriptions, increases the expression of both nuclear and mitochondrial-encoded genes of oxidative metabolism, induces mitochondrial biogenesis and plays an essential role in energy homeostasis. The region in which the $P G C-1 \alpha$ gene is situated, chromosome $4 \mathrm{p} 15.1$, has been shown to be associated with fasting insulin levels in Pima Indians (12), and to be linked to SBP and plasma free 
Table 6. Comparison of Genotype and Allele Frequencies of G482S Polymorphism in Different Populations

\begin{tabular}{|c|c|c|c|c|c|c|c|c|c|c|c|c|c|}
\hline & & \multicolumn{4}{|c|}{ Patients } & \multicolumn{5}{|c|}{ Controls } & \multicolumn{3}{|c|}{ 482S allele frequency } \\
\hline & & $482 \mathrm{GG}$ & $482 \mathrm{GS}$ & $482 S S$ & Total & $482 \mathrm{GG}$ & $482 \mathrm{GS}$ & $482 \mathrm{SS}$ & Total & $p$ & $\begin{array}{c}\text { Case } \\
(\%)\end{array}$ & $\begin{array}{c}\text { Control } \\
(\%)\end{array}$ & $p$ \\
\hline Danish initial study (14) & $\mathrm{T} 2 \mathrm{DM} / \mathrm{NGT}$ & 186 & 200 & 68 & 454 & 97 & 80 & 21 & 198 & 0.1100 & 37.00 & 30.80 & 0.0320 \\
\hline Danish replicated study (14) & T2DM/NGT & 76 & 97 & 28 & 201 & 146 & 116 & 31 & 293 & 0.0300 & 38.10 & 30.40 & 0.0135 \\
\hline Danish combined study (14) & $\mathrm{T} 2 \mathrm{DM} / \mathrm{NGT}$ & 262 & 297 & 96 & 655 & 243 & 196 & 52 & 491 & 0.0035 & 37.30 & 30.50 & 0.0007 \\
\hline French study (16) & $\mathrm{T} 2 \mathrm{DM} / \mathrm{NDM}$ & 280 & 284 & 95 & 659 & 323 & 327 & 98 & 748 & 0.7740 & 36.00 & 35.00 & 0.8820 \\
\hline Austrian study $(17)^{*}$ & HT/NT & 231 & 231 & 47 & 509 & 286 & 315 & 103 & 704 & 0.0140 & 31.93 & 37.00 & 0.0100 \\
\hline Japanese study (15) & $\mathrm{T} 2 \mathrm{DM} / \mathrm{NDM}$ & - & - & - & - & 178 & 249 & 110 & 537 & & - & 43.67 & - \\
\hline Chinese study & HD/NDM & 155 & 255 & 84 & 494 & 185 & 264 & 106 & 555 & 0.4050 & 42.81 & 42.88 & 0.9750 \\
\hline
\end{tabular}

T2DM, type 2 diabetes mellitus; NGT, normal glucose tolerance; NDM, non-diabetic subjects; HT, hypertension/hypertensive; NT, normotensive; HD, hypertension and diabetes. ${ }^{*}$ Results for combined male and female subjects from Oberkofler et al. (17). \# Results were from the present study.

fatty acid levels in Dutch dyslipidemic families (13) and to high BMI in Utah pedigrees (33). Amino acids 338-403 of $P G C-1 \alpha$ contain a major domain of interaction with PPAR $\gamma$, and thereby impact the ability of cells to uptake fatty acids and store them in adipocytes, while residues 403-570 of $P G C-1 \alpha$ interact with myocyte enhancer factor $2 \mathrm{C}$ (MEF2C), which is responsible for activation of the GLUT4 gene $(6,8)$. One study showed that $P G C-1 \alpha$ expression was significantly reduced in both T2DM subjects and family history-positive nondiabetic subjects (34). These data suggested that the $P G C$ - $1 \alpha$ gene might contribute to the pathogenesis of hypertension and diabetes.

It has been reported that the $482 \mathrm{~S}$ allele was associated with a reduction in the prevalence of hypertension (OR, 0.42 ; 95\% CI, 0.25-0.73) in male Europeans (17). On the other hand, Ek et al. found that the G482S polymorphism was significantly associated with T2DM (the $482 \mathrm{~S}$ allele frequency was $37.3 \%$ vs. $30.5 \%$, respectively, $p=0.0007$ ) and contributed 1.34-fold (95\% CI, 1.13-1.59) relative risk of T2DM in a Danish population (14). However, there were no significant associations between this polymorphism and hypertension or T2DM in Chinese, which finding was similar to those of previous studies in French Caucasians and Japanese $(15,16)$. Given our sample sizes, we had $>65 \%$ power to detect an OR of 1.34 at a significance level of 0.05 . Thus, if G482S polymorphism had an effect in Chinese similar to that seen in the Danish population, we would have had sufficient power to detect it. Two previous studies suggested that the G482S and other polymorphisms and haplotype combinations in the $P G C-1 \alpha$ gene had metabolic consequences on lipid metabolism and played important roles in obesity (35, 36). In order to remove the confounding effect of obesity, we examined the associations of polymorphisms with hypertension and diabetes stratified based on obesity. The stratification analysis showed that there were no significant differences in genotype, allele, or haplotype combination frequencies. Multivariate logistic regression analysis also showed no association of G482S polymorphism with hypertension and diabetes. So the G482S polymorphism in the $P G C$ - $1 \alpha$ gene is unlikely to be a major genetic factor of hypertension and diabetes in the Chinese population.

For another polymorphism, $+1302 \mathrm{G}>\mathrm{A}$, the minor allele $+1302 \mathrm{~A}$ frequency was lower among diabetic subjects compared to glucose-tolerant Danish control subjects (19.7\% vs. $23.9 \%, p=0.02$ ) in the combined study of Ek et al. (14). This relationship was not replicated in our study or in the previous study on the Japanese population (15).

Previous haplotype analysis showed that the +1302A$482 \mathrm{~S}$ haplotype was attributed to the risk of T2DM in the Japanese population (4.6\% vs. $1.3 \%, p=0.00003)(15)$, whereas this association was not confirmed in our study. This discrepancy may be explained as follows. Although the frequencies of the two SNPs in control subjects were similar between Chinese and Japanese individuals (for G482S, 185/ 264/106 vs. 178/249/110, $p=0.839$; for + 1302GA, 340/ $186 / 29$ vs. $320 / 184 / 33, p=0.749)$, the haplotype + 1302A$482 \mathrm{~S}$ is relatively rare in the Chinese population $(6 / 2,098$ [0.29\%] vs. 52/1,908 [2.73\%], $p=0.001)$. Given the comparable sample sizes, our power to detect a significant effect may be lower than that of the study in Japanese subjects.

As Table 6 shows, the $482 \mathrm{~S}$ allele frequency distribution of the G482S polymorphism was significantly different among different populations (14-17). For example, the 482S allele frequency was higher in the Chinese population than in Caucasians. Such a difference of allelic frequency among populations may have produced the discrepant results. Other likely causes may have been the poor metabolic characterization (particularly regarding glucose tolerance) and sample biases in ascertainment of the study groups used in the studies listed in Table 6. In our study we determined associations of polymorphisms with two closely related phenotypic traits. However, it should be taken into account that the previously opposite associations of the G482S polymorphism with T2DM (14) and hypertension (17) may overcome the factual association of this polymorphism with diabetes and hypertension when these two phenotypic traits were analyzed to- 
gether. Another reference group consisting of hypertensives only or diabetics only will be needed in the future.

In summary, we did not confirm the effects of the G482S and the $+1302 \mathrm{G}>\mathrm{A}$ polymorphisms in the $P G C-1 \alpha$ gene on the risk of essential hypertension and T2DM in the Chinese population. Additional studies should be performed to clarify the contribution of variations of the $P G C-1 \alpha$ gene to the pathogenesis of hypertension and T2DM in a variety of ethnic groups.

\section{References}

1. Timar O, Sestier F, Levy E: Metabolic syndrome X: a review. Can J Cardiol 2000; 16: 779-789.

2. Zavaroni I, Mazza S, Dall'Aglio E, Gasparini P, Passeri M, Reaven GM: Prevalence of hyperinsulinaemia in patients with high blood pressure. J Intern Med 1992; 231: 235240.

3. Pollare T, Lithell H, Berne C: Insulin resistance is a characteristic feature of primary hypertension independent of obesity. Metabolism 1990; 39: 167-174.

4. Cockram CS: The epidemiology of diabetes mellitus in the Asia-Pacific region. Hong Kong Med J 2000; 6: 43-52.

5. Willson TM, Cobb JE, Cowan DJ, et al: The structure-activity relationship between peroxisome proliferator-activated receptor gamma agonism and the antihyperglycemic activity of thiazolidinediones. J Med Chem 1996; 39: 665668.

6. Puigserver $\mathrm{P}, \mathrm{Wu} \mathrm{Z}$, Park $\mathrm{CW}$, Graves $\mathrm{R}$, Wright $\mathrm{M}$, Spiegelman BM: A cold-inducible coactivator of nuclear receptors linked to adaptive thermogenesis. Cell 1998; 92: 829-839.

7. Vega RB, Huss JM, Kelly DP: The coactivator PGC-1 cooperates with peroxisome proliferator-activated receptor alpha in transcriptional control of nuclear genes encoding mitochondrial fatty acid oxidation enzymes. Mol Cell Biol 2000; 20: 1868-1876.

8. Michael LF, Wu Z, Cheatham RB, et al: Restoration of insulin-sensitive glucose transporter (GLUT4) gene expression in muscle cells by the transcriptional coactivator PGC1. Proc Natl Acad Sci USA 2001; 98: 3820-3825.

9. Yoon JC, Puigserver P, Chen G, et al: Control of hepatic gluconeogenesis through the transcriptional coactivator PGC-1. Nature 2001; 413: 131-138.

10. Esterbauer H, Oberkofler H, Krempler F, Patsch W: Human peroxisome proliferator activated receptor gamma coactivator 1 (PPARGC1) gene: cDNA sequence, genomic organization, chromosomal localization, and tissue expression. Genomics 1999; 62: 98-102.

11. Perusse L, Rice T, Chagnon YC, et al: A genome-wide scan for abdominal fat assessed by computed tomography in the Quebec Family Study. Diabetes 2001; 50: 614-621.

12. Pratley RE, Thompson DB, Prochazka M, et al: An autosomal genomic scan for loci linked to prediabetic phenotypes in Pima Indians. J Clin Invest 1998; 101: 1757-1764.

13. Allayee H, de Bruin TW, Michelle Dominguez K, et al: Genome scan for blood pressure in Dutch dyslipidemic families reveals linkage to a locus on chromosome 4p. Hypertension 2001; 38: 773-778.

14. Ek J, Andersen G, Urhammer SA, et al: Mutation analysis of peroxisome proliferator-activated receptor- $\gamma$ coactivator1 (PGC-1) and relationships of identified amino acid polymorphisms to type II diabetes mellitus. Diabetologia 2001; 44: 2220-2226.

15. Hara K, Tobe $\mathrm{K}$, Okada $\mathrm{T}$, et al: A genetic variation in the PGC-1 gene could confer insulin resistance and susceptibility to type II diabetes. Diabetologia 2002; 45: 740-743.

16. Lacquemant C, Chikri M, Boutin P, Samson C, Froguel P: No association between the G482S polymorphism of the proliferator-activated receptor- $\gamma$ coactivator-1 (PGC-1) gene and type II diabetes in French Caucasias. Diabetologia 2002; 45: 602-603.

17. Oberkofler $\mathrm{H}$, Holzl B, Esterbauer $\mathrm{H}$, et al: Peroxisome proliferator-activated receptor-gamma coactivator-1 gene locus: associations with hypertension in middle-aged men. Hypertension 2003; 41: 368-372.

18. Perloff D, Grim C, Flack J, et al: Human blood pressure determination by sphygmomanometry. Circulation 1993; 88: 2460-2470.

19. Zhou BF, Cooperative Meta-Analysis Group of Working Group on Obesity in China: Predictive values of body mass index and waist circumference for risk factors of certain related diseases in Chinese adults: study on optimal cut-off points of body mass index and waist circumference in Chinese adults. Asia Pac J Clin Nutr 2002; 11: S685-S693.

20. Gu D, Huang G, Wu X, Duan X: Relationship between body mass index and major cardiovascular diseases in Chinese population. Zhonghua Yi Xue Za Zhi 2002; 82: 10181021 (in Chinese).

21. Zhou BF: Effect of body mass index on all-cause mortality and incidence of cardiovascular diseases - report for metaanalysis of prospective studies open optimal cut-off points of body mass index in Chinese adults. Biomed Environ Sci 2002; 5: 245-252.

22. Esterbauer $\mathrm{H}, \mathrm{Schneitler} \mathrm{C}$, Oberkofler $\mathrm{H}$, et al: A common polymorphism in the promoter of UCP2 is associated with decreased risk of obesity in middle-aged humans. Nat Genet 2001; 28: 178-183.

23. Horikawa $\mathrm{Y}$, Oda $\mathrm{N}$, Cox $\mathrm{NJ}$, et al: Genetic variation in the gene encoding calpain-10 is associated with type 2 diabetes mellitus. Nat Genet 2000; 26: 163-175.

24. Orho-Melander M, Klannemark M, Svensson MK, Ridderstrale M, Lindgren CM, Groop L: Variants in the calpain10 gene predispose to insulin resistance and elevated free fatty acid levels. Diabetes 2002; 51: 2658-2664.

25. Matthaei S, Stumvoll M, Kellerer M, Haring HU: Pathophysiology and pharmacological treatment of insulin resistance. Endocr Rev 2000; 21: 585-618.

26. Altshuler D, Hirschhorn JN, Klannemark M, et al: The common PPARgamma Pro12Ala polymorphism is associated with decreased risk of type 2 diabetes. Nat Genet 2000; 26: 76-80.

27. Sugawara A, Takeuchi K, Uruno A, et al: Differential effects among thiazolidinediones on the transcription of thromboxane receptor and angiotensin II type 1 receptor genes. Hypertens Res 2001; 24: 229-233.

28. Sugawara A, Takeuchi K, Uruno A, et al: Transcriptional suppression of type 1 angiotensin II receptor gene expression by peroxisome proliferator-activated receptor-gamma in vascular smooth muscle cells. Endocrinology 2001; 142: 
3125-3134.

29. Griendling KK, Ushio-Fukai M, Lassegue B, Alexander RW: Angiotensin II signaling in vascular smooth muscle: new concepts. Hypertension 1997; 29: 366-373.

30. Berk BC: Angiotensin II signal transduction in vascular smooth muscle: pathways activated by specific tyrosine kinases. J Am Soc Nephrol 1999; 10: S62-S68.

31. Berry C, Touyz R, Dominiczak AF, Webb RC, Johns DG: Angiotensin receptors: signaling, vascular pathophysiology, and interactions with ceramide. Am J Physiol Heart Circ Physiol 2001; 281: H2337-H2365.

32. Sugawara A, Takeuchi K, Uruno A, Kudo M, Sato K, Ito S: Effects of mitogen-activated protein kinase pathway and co-activator CREP-binding protein on peroxisome proliferator-activated receptor- $\gamma$-mediated transcription suppression of angiotensin II type 1 receptor gene. Hypertens Res 2003; 26: 623-628.
33. Stone $\mathrm{S}$, Abkevich V, Hunt SC, et al: A major predisposition locus for severe obesity, at 4p15-p14. Am J Hum Genet 2002; 70: 1459-1468.

34. Patti ME, Butte AJ, Crunkhorn S, et al: Coordinated reduction of genes of oxidative metabolism in humans with insulin resistance and diabetes: potential role of PGC1 and NRF1. Proc Natl Acad Sci U SA 2003; 100: 8466-8471.

35. Esterbauer H, Oberkofler H, Linnemayr V, et al: Peroxisome proliferator-activated receptor-gamma coactivator-1 gene locus: associations with obesity indices in middleaged women. Diabetes 2002; 51: 1281-1286.

36. Muller YL, Bogardus C, Pedersen O, Baier L: A Gly482Ser missense mutation in the peroxisome proliferator-activated receptor gamma coactivator-1 is associated with altered lipid oxidation and early insulin secretion in Pima Indians. Diabetes 2003; 52: 895-898. 